\title{
Endogenous folates and single-carbon metabolism in the ovarian follicle, oocyte and pre-implantation embryo
}

\author{
W Y Kwong, S J Adamiak, A Gwynn, R Singh and K D Sinclair \\ School of Biosciences, University of Nottingham, Sutton Bonington Campus, Loughborough, \\ Leicestershire LE12 5RD, UK \\ Correspondence should be addressed to K D Sinclair; Email: kevin.sinclair@nottingham.ac.uk
}

\begin{abstract}
Maternal B-vitamin status at conception can affect fertility and the health of offspring. This study details transcript expression for genes encoding key enzymes in the linked methionine/folate cycles in the bovine oocyte, somatic cells of the ovarian follicle and pre-implantation embryo. Transcripts for all 12 enzymes that were studied and for the two folate receptors (FOLR1 and FOLR2) and reduced folate carrier (SLC19A1) were expressed in liver cells, but transcripts for betaine-homocysteine methyltransferase and methionine adenosyl transferase $1 \mathrm{~A}$ were absent in all ovarian cells, and transcripts for FOLR2 were absent in embryonic cells. Transcripts for glycine methyltransferase were also absent/weak in cumulus and granulosa cells. The absence of these enzymes could have a profound effect on single-carbon metabolism within the ovary and pre-implantation embryo. Immunocytochemical analysis revealed SLC19A1 protein expression on the plasma and basal-lateral membranes of the pre-implantation embryo. The folate antagonist methotrexate (MTX) enters the cell via SLC19A1, and in the current study, MTX inclusion in bovine/ovine culture media at either 1 or $10 \mu \mathrm{M}$ from the 1-cell stage inhibited embryo development beyond the 8-cell stage. Hypoxanthine and thymidine $(100 \mu \mathrm{M})$ increased the proportion of embryos that developed to blastocysts, but the cell number was reduced by $20 \%$. The reduced uptake of $\left[{ }^{35} \mathrm{~S}\right]$ methionine into intra-cellular $S$-adenosylmethionine and $S$-adenosylhomocysteine pools, together with reduced uptake of glutamate and tryptophan, was consistent with depleted intra-cellular pools of reduced folates. These data provide an insight into the importance of maternal dietary folate/B-vitamin status during the peri-conceptional period.

Reproduction (2010) 139 705-715
\end{abstract}

\section{Introduction}

Maternal B-vitamin status of intending mothers can have a major bearing on pregnancy establishment and term delivery (Tamura \& Piccianno 2006, Forges et al. 2007). By way of example, whereas poor pre-conception vitamin $B_{6}$ status reduced the probability of pregnancy establishment, deficiency of both vitamin $\mathrm{B}_{6}$ and vitamin $B_{12}$ was associated with early pregnancy loss and recurrent miscarriage (Reznikoff-Etiévant et al. 2002, Ronnenberg et al. 2007). Furthermore, in one recent study, cobalamin $\left(\mathrm{B}_{12}\right)$ deficiency was prevalent in at least one partner in around $40 \%$ of couples presenting for unexplained infertility (Pront et al. 2009). A significant proportion of women presenting for fertility treatment are known to be polymorphic for genes for at least two key enzymes (i.e. 5,10-methylenetetrahydrofolate reductase (MTHFR) and solute carrier family 19, member 1 (SLC19A1)) involved in folate metabolism (Altmäe et al. 2010). Mild hyperhomocysteinaemia is prevalent in subjects polymorphic for a number of enzymes involved in folate/methionine metabolism (Midttun et al. 2007), and total homocysteine concentrations, measured in follicular fluid, are sensitive to dietary intakes of folic acid (Boxmeer et al. 2008) and are associated with pregnancy outcome in clinical IVF cycles (Haggarty et al. 2006, Pacchiarotti et al. 2007).

A number of putative mechanisms have been proposed to explain these observations, mostly centring on the effects of homocysteine on placental vascular disease (including placental infarction and abruption), which is related to the production of inflammatory cytokines, oxidative stress and apoptosis (discussed by Ebisch et al. (2007) and Forges et al. (2007)). Although the effects of folate/vitamin $B_{12}$ deficiency on the follicleenclosed oocyte and pre-implantation embryo are generally acknowledged, there has been very little work conducted on these specific cell types. In a sheep model of dietary vitamin $B_{12}$ and folate deficiency during the peri-conceptional period (encompassing the periods of oocyte growth and post-fertilisation development to the blastocyst stage), we reported on the extent to which availability of dietary methyl groups can perturb homocysteine metabolism in embryo donor ewes, leading to epigenetic modifications to DNA methylation in offspring that became obese, insulin 
resistant and hypertensive (Sinclair et al. 2007). In this model, deranged single-carbon metabolism, leading to elevated intra-cellular homocysteine and reduced $S$-adenosylmethionine (SAM) concentrations, altered the expression of a number of oocyte- and granulosa cell-specific transcripts associated with ovarian follicular development and responsiveness to $\mathrm{FSH}$ (Kanakkaparambil et al. 2009), effects broadly consistent with those following ovarian stimulation in folatedeficient human IVF cycles (Twigt et al. 2009).

In spite of these observations, little is known about the uptake and metabolism of folates and other B-vitamins within the ovarian follicle, oocyte and pre-implantation embryo. Indeed, the nature and extent of single-carbon metabolism within these cells are not understood (Sinclair \& Singh 2007). Given the importance attached to folic acid in the diet of intending mothers aimed, primarily, at reducing the incidence of neural tube defects (Lucock 2000, Smith et al. 2008, Osterhues et al. 2009), it seems surprising that so little attention has been directed towards understanding its metabolism and that of related B-vitamins by the follicle-enclosed oocyte and pre-implantation embryo. We have previously shown that human embryonic stem cells express transcripts for most of the methyl cycle enzymes illustrated in Fig. 1 (Steele et al. 2005), and at the time of going to press, a report had just emerged to indicate that transcripts for most of these enzymes are also present in human germinal vesicle (GV) oocytes (Benkhalifa et al. 2010). However, transcript expression for these enzymes and folate receptors in mammalian embryos and somatic cells within the ovarian follicle has not been investigated. Furthermore, the functional significance of altering folate metabolism in these cells is poorly understood.

O'Neill (1998) cultured mouse zygotes in the presence of varying doses of methotrexate (MTX), a structural folate analogue and antagonist, either in the presence or in the absence of exogenous folic acid, and reported on the proportion of zygotes that developed to the blastocyst stage. He concluded that the preimplantation embryo has an absolute requirement for reduced folate, principally for thymidine synthesis, which is met entirely by endogenous sources accumulated, presumably, during the protracted period of oocyte growth that occurs during ovarian folliculogenesis. The study, however, did not go into detail sufficient to provide a clear insight into the underlying mechanisms.

The purpose of the present study, therefore, was twofold. First, to confirm or otherwise the expression of transcripts and proteins for key enzymes and receptors involved in folate and single-carbon metabolism in oocytes, the different somatic cell types within the ovarian follicle, and in blastocysts. Such information would provide a novel and important initial insight into the extent to which these important cycles might function within the ovarian follicle and early embryo, and the degree to which the female gamete and early embryo may be affected directly by maternal diet and/or culture media composition. Secondly, this study sought to extend the observations of $\mathrm{O}^{\prime} \mathrm{Neill}$ (1998) by considering the detailed metabolic and developmental

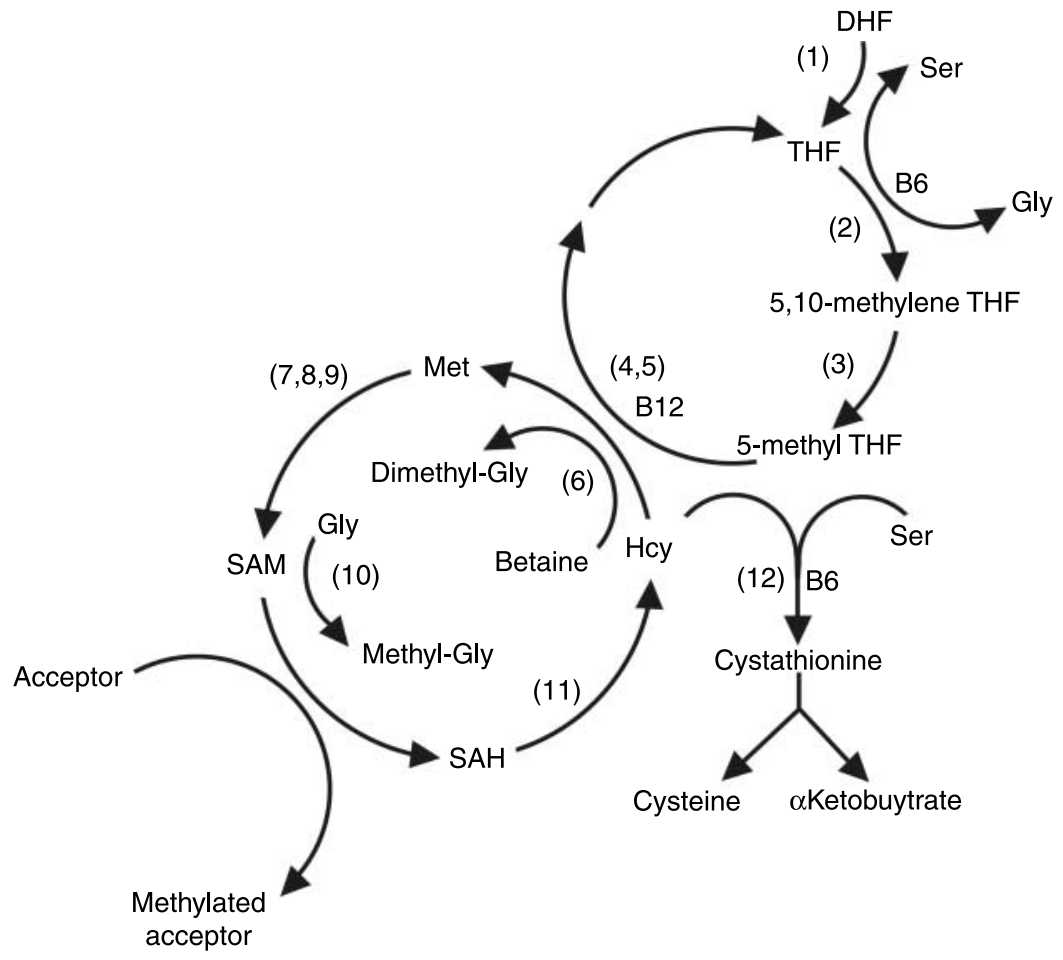

Figure 1 Combined methionine and folate cycles identifying key metabolites and enzymes investigated in the current study. Metabolites: dihydrofolate (DHF), tetrahydrofolate (THF), serine (Ser), glycine (Gly), pyridoxal phosphate (B6), methylcobalamin (B12), methionine (Met), $S$-adenosylmethionine (SAM), S-adenosylhomocysteine (SAH), homocysteine (Hcy). Enzymes: dihydrofolate reductase (DHFR) (1), serine hydroxymethyl transferase (mSHMT) (2), 5,10-methylene THF reductase (MTHFR) (3), methionine synthase (MTR) (4), methionine synthase reductase (MTRR) (5), betaine-homocysteine methyltransferase (BHMT) (6), methionine adenosyl transferase 1A (MAT1A) (7), 2A (MAT2A) (8), 2B (MAT2B) (9), glycine methyltransferase (GNMT) (10), SAH-hydrolase (SAHH) (11), cystathionine $\beta$-synthase (CBS) (12). 
consequences of disturbing endogenous reduced folate metabolism, through the actions of MTX, for zygotes from two alternative species (i.e. the sheep and cow).

\section{Results}

\section{Transcript expression and immunostaining}

Transcript expression for each of the enzymes listed in Fig. 1 is presented for bovine cumulus, granulosa and thecal cells, oocytes, day 8 blastocysts and liver in Fig. 2. Of note was the presence of all transcripts in the liver, but the absence of transcripts for betaine-homocysteine methyltransferase $(B H M T)$ in all cells of the ovarian follicle, including the oocyte, and in day 8 blastocysts. Also absent, or expressed at very low levels, in these cells were transcripts for the enzyme methionine adenosyl transferase 1A (MAT1A). Transcripts for glycine methyltransferase (GNMT) were absent/weak in cumulus

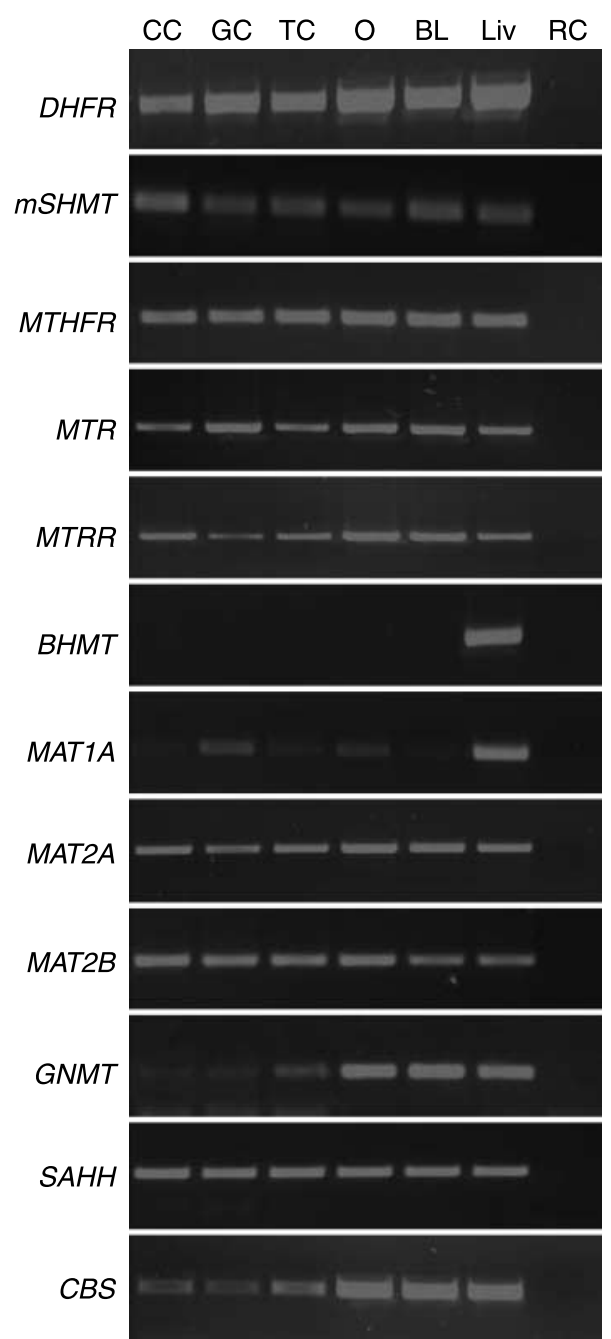

Figure 2 Transcript expression for each of the methionine/folate cycle enzymes listed in Fig. 1 in bovine ovarian follicular cells, oocytes, day 8 blastocysts and liver. CC, cumulus cells; GC, granulosa cells; TC, thecal cells; O, oocytes; BL, blastocysts; Liv, liver; RC, reagent control. and granulosa cells, and expressed at very low levels in thecal cells, but were abundantly present in the oocyte and pre-implantation embryo. Similarly, transcripts for $C B S$, the rate-limiting enzyme in the trans-sulphuration pathway, were expressed at very low levels in cumulus, granulosa and thecal cells, but were abundantly expressed in the oocyte and blastocyst. Transcripts for FOLR1 and SLC19A1, but not for FOLR2, were expressed in the oocyte, and during the later stages of bovine embryo development up to the blastocyst stage (Fig. 3). Western analysis confirmed the specificity of the antibody used for immunocytochemistry of SLC19A1 (Fig. 4). A single band was present at $72 \mathrm{kDa}$, which was absent when the antibody was treated with a blocking peptide. Immunostaining of bovine oocytes and embryos revealed plasma- and basal-lateral-membrane localisation of SLC19A1 protein at all stages of development studied (Fig. 5).

\section{Developmental and metabolic actions of MTX during embryo culture}

In the initial experiment, putative bovine zygotes were transferred to synthetic oviductal fluid (SOF) media containing varying concentrations of MTX $24 \mathrm{~h}$ after the onset of fertilisation. Neither the percentage of inseminated oocytes that cleaved following insemination nor the percentage that developed to the 8-cell stage were affected by MTX (Table 1). However, effects of MTX at the higher doses were evident by day 7 , and virtually no embryos were present by day 8 when cultured with $10 \mu \mathrm{M}$ MTX. Cell number in day 8 blastocysts was also reduced ( $P=0.022)$ at $1 \mu \mathrm{M}$ MTX, but the percentage of TUNEL-positive cells was unaltered.

To overcome the toxic effects of $10 \mu \mathrm{M}$ MTX on purine and pryimidine synthesis, bovine zygotes were subsequently cultured in the presence of hypoxanthine $(100 \mu \mathrm{M})$ and thymidine $(100 \mu \mathrm{M})$. The effect was to rescue a large percentage of embryos, but residual

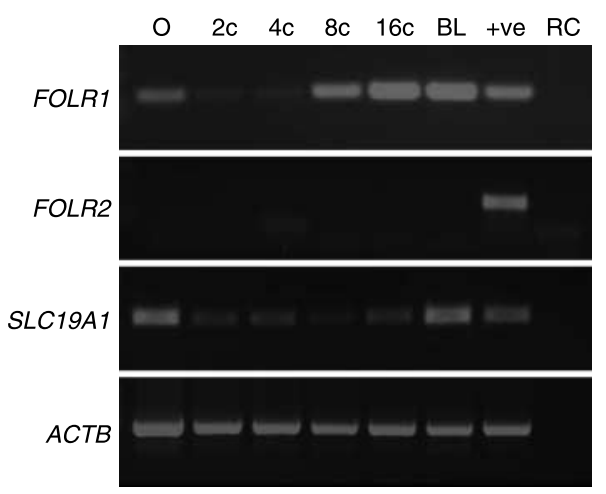

Figure 3 Transcript expression for folate receptors 1 and 2 (FOLR1 and FOLR2) and the reduced folate carrier (SLC19A1) in bovine oocytes and pre-elongation embryos. O, oocyte; $2 \mathrm{c}, 2$ cell; 4c, 4 cell; $8 \mathrm{c}, 8$ cell; $16 \mathrm{c}$, 16 cell; BL, day 8 blastocyst, + ve, positive control (spleen for FOLR2 and liver for other transcripts), RC, reagent control. 


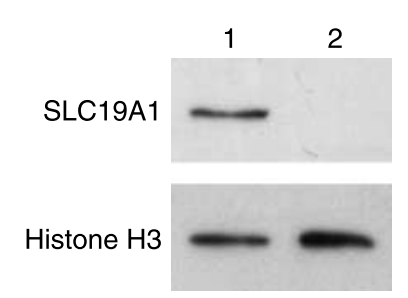

Figure 4 Validation of SLC19A1 antibody by western blotting. Proteins extracted from 50 bovine oocytes were separated by SDS-PAGE. PVDF membrane was then incubated with SLC19A1 antibody (lane 1) or SLC19A1 antibody pre-treated with tenfold excess blocking peptide (lane 2). Both blots were re-probed with histone $\mathrm{H} 3$ antibody.

effects, in terms of reduced cell number, remained (Table 2). The percentage of TUNEL-positive cells was not affected by treatment.

These experiments were extended to consider the culture of ovine zygotes. As was observed with bovine zygotes, culture in the presence of $10 \mu \mathrm{M}$ MTX inhibited development beyond the 8-16-cell stage, but the inclusion of $100 \mu \mathrm{M}$ hypoxanthine and thymidine rescued a large percentage of embryos, which developed to the blastocyst stage by day 7 (Table 3 ). Once again, however, total cell number was reduced $(P<0.001)$ in MTX-treated embryos. As a third treatment, tetrahydrofolate (THF), at $25 \mu \mathrm{M}$, was added in the hope of eliminating the residual toxic effects of MTX on embryo development and cell number. In this regard, THF proved ineffective. However, in this experiment, the inclusion of hypoxanthine and thymidine was effective in rescuing the percentage of zygotes that developed to the blastocyst stage, although residual effects on cell number remained (Table 4). The incorporation of $\left[{ }^{35} \mathrm{~S}\right]$ methionine into intra-cellular SAM and $S$-adenosylhomocysteine (SAH) pools was also lower $(P<0.05)$ for embryos cultured in the presence of MTX, irrespective of the inclusion of hypoxanthine, thymidine and THF, than for control embryos. Adjusting these values for cell number, however, eliminated these treatment differences.

Finally, amino acid turnover in ovine blastocysts was determined by culturing day 6.5 embryos for $12 \mathrm{~h}$ in microdrops under oil and by measuring amino acid concentrations in media both before and after culture. Overall, the pattern of amino acid turnover (data not presented) resembled that of previous studies (e.g. Partridge \& Leese 1996) with ruminant embryos. Of the 20 amino acids measured, only two were altered $(P<0.01)$ by culture treatment (Fig. 6). The uptake of both glutamate and tryptophan was reduced in the presence of MTX irrespective of the presence of THF.

\section{Discussion}

The current study details, for the first time, transcript expression for genes encoding key enzymes involved in the linked methionine-folate cycles in the bovine oocyte, and the various somatic cells of the ovarian follicle and pre-implantation bovine embryo. While it is acknowledged that the presence of transcripts for these enzymes does not inform on their functional activity, a number of important conclusions can be drawn from the absence of transcripts for specific enzymes. Of note were the absence of transcripts for the methionine cycle enzyme $B H M T$, and absence or very low expression of MAT1A in the bovine ovary, oocyte and pre-implantation embryo. Transcripts for GNMT were also absent/weak

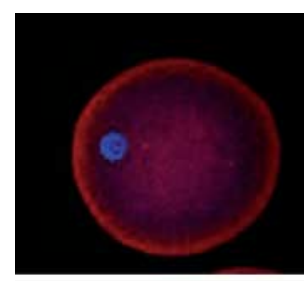

Oocyte
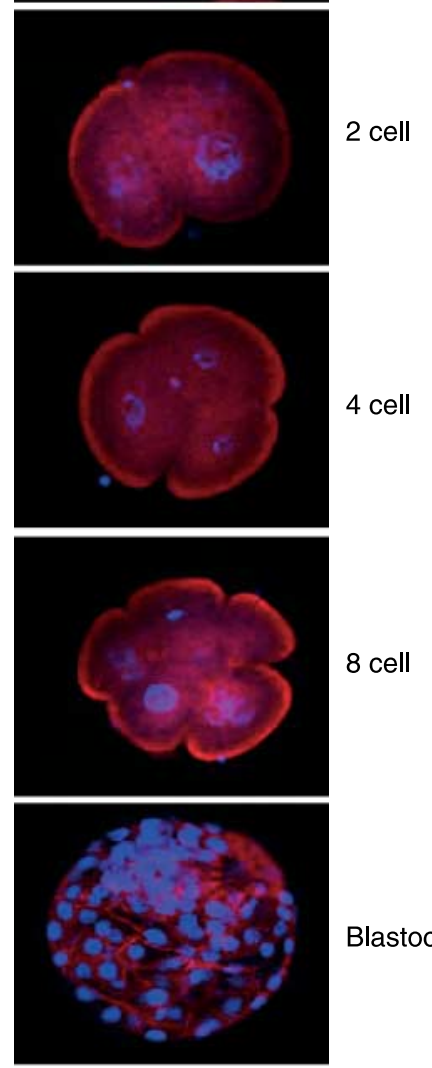

Blastocyst

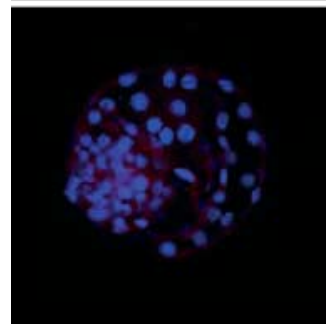

Blastocyst

(negative control) 
Table 1 Culture of bovine zygotes in the presence of different concentrations of methotrexate.

\begin{tabular}{|c|c|c|c|c|c|}
\hline Treatment & Control & $0.5(\mu \mathrm{M})$ & $1.0(\mu \mathrm{M})$ & $10.0(\mu \mathrm{M})$ & Significance $P$ \\
\hline Replicate experiments & 4 & 4 & 4 & 4 & \\
\hline Oocytes matured & 240 & 240 & 240 & 235 & \\
\hline Cleaved of inseminated, \% & $82.9 \pm 2.7$ & $83.8 \pm 2.6$ & $83.4 \pm 2.7$ & $84.6 \pm 2.6$ & NS \\
\hline Percentage of 8 cells $^{\mathrm{a}}$ & $41.9 \pm 4.8$ & $42.4 \pm 4.8$ & $37.7 \pm 4.7$ & $43.2 \pm 4.8$ & NS \\
\hline \multicolumn{6}{|l|}{ Blastocysts of cleaved } \\
\hline & \multicolumn{3}{|c|}{ Blastocyst cell number ${ }^{b}$} & $1.0 \pm 1.0$ & 0.004 \\
\hline Total & $97.0 \pm 4.9$ & $91.9 \pm 4.8$ & $79.2 \pm 4.4$ & - & 0.022 \\
\hline Inner cell mass & $46.9 \pm 4.9$ & $35.5 \pm 4.9$ & $32.5 \pm 4.9$ & - & 0.053 \\
\hline Trophectoderm & $72.2 \pm 6.0$ & $86.3 \pm 6.6$ & $66.5 \pm 5.8$ & - & 0.066 \\
\hline TUNEL, \% & $5.3 \pm 1.1$ & $6.4 \pm 1.3$ & $7.8 \pm 1.5$ & - & NS \\
\hline
\end{tabular}

${ }^{\mathrm{a}}$ Forty-eight hours following initiation of fertilisation. ${ }^{\mathrm{b}}$ Number of blastomeres in the inner cell mass and trophectoderm does not match total because these cells could not be distinguished in all embryos.

in cumulus and granulosa cells, with low level expression in thecal cells. The absence or low expression of transcripts for these enzymes may have profound implications for how single-carbon metabolism operates within the ovary and pre-implantation embryo. The bovine oocyte and pre-implantation embryo were, however, found to express transcripts for FOLR1 and $S L C 19 A 1$, but not for FOLR2. We previously reported transcripts for FOLR1 but not for FOLR2 in human ES cells (Steele et al. 2005). Immunocytochemical analysis revealed that SLC19A1 protein was expressed on the plasma and basal-lateral membranes of the preimplantation embryo at all stages of development up to and including the blastocyst stage. The structural folate analogue and antagonist MTX is known to enter the cell via SLC19A1 (Bosson 2003). In the current study, MTX inclusion in culture media at either 1 or $10 \mu \mathrm{M}$ from the 1-cell stage inhibited embryo development beyond but not prior to the 8-cell stage, indicating that there were sufficient intra-cellular reserves of reduced folates, presumably acquired during oocyte growth, to sustain initial cell-cycle progression following fertilisation. The inclusion of thymidine and hypoxanthine significantly increased the proportion of MTX-treated embryos that developed beyond eight cells. However, blastomere number was reduced by around $20 \%$ in these embryos compared with the controls, although the proportion of apoptotic (specifically TUNEL-positive) cells was unaltered. As the decrease in cell number was proportionately similar for the inner cell mass (ICM) and trophectoderm (TE), these results point to a general slowing down of cell division rather than to programmed cell death as the cause. The reduced uptake of the amino acids glutamate and tryptophan by day 8 blastocysts in the presence of MTX is consistent with there being a depleted intra-cellular pool of reduced folates in these embryos. In contrast, the reduced uptake of $\left[{ }^{35} \mathrm{~S}\right]$ methionine into intra-cellular SAM and $\mathrm{SAH}$ pools is more likely to be related to the reduction in blastomere number.

\section{Methionine cycle enzymes}

The general absence of transcripts for BHMT, MAT1 and GNMT in somatic cells of the bovine follicle, and for BHMT and MAT1 in the oocyte and blastocyst, is significant for it indicates that under physiological conditions, these cells are not best equipped to metabolise high concentrations of methionine. However, supra-physiological concentrations of methionine are present in many commercially available cell and embryo-culture media formulations (Steele et al. 2005), including that (SOFBSAaa) used in the current study. At present, the consequences of this, in terms of effects on intra-cellular transmethylation and epigenetic programming, are not known, but are the subject of ongoing investigations at our laboratory. BHMT (EC 2.1.1.5) is a zinc metalloenzyme which uses preformed methyl groups from dietary betaine, or betaine derived from choline, for the methylation of homocysteine to methionine (Fig. 1). Activity and expression measurements indicate that BHMT is mainly located in the liver where, in the rat, it can process up to $25 \%$ of

Table 2 Culture of bovine zygotes in the presence of $10 \mu \mathrm{M}$ methotrexate (MTX) with $100 \mu \mathrm{M}$ hypoxanthine $(\mathrm{H})$ and $100 \mu \mathrm{M}$ thymidine $(\mathrm{T})$.

\begin{tabular}{lccc}
\hline Treatment & Control & MTX $+\mathbf{H}+\mathbf{T}$ & Significance $\boldsymbol{P}$ \\
\hline $\begin{array}{l}\text { Replicate experiments } \\
\text { Oocytes matured }\end{array}$ & 9 & 9 & \\
Cleaved of & 493 & 504 & \\
$\quad$ inseminated, \% & $78.7 \pm 1.8$ & $81.0 \pm 1.8$ & $\mathrm{NS}$ \\
$\begin{array}{l}\text { Blastocysts of cleaved } \\
\quad \text { Day 8, \% }\end{array}$ & & & \\
Blastocyst cell & $23.2 \pm 2.1$ & $14.0 \pm 1.7$ & $<0.001$ \\
$\quad$ number & & & \\
$\quad$ Total & & & \\
$\quad$ Inner cell mass & $115.2 \pm 2.8$ & $85.5 \pm 1.9$ & $<0.001$ \\
$\quad$ Trophectoderm & $71.2 \pm 2.2$ & $37.7 \pm 1.7$ & $<0.001$ \\
$\quad$ TUNEL, \% & $3.4 \pm 0.4$ & $61.6 \pm 2.2$ & 0.006 \\
& & $3.3 \pm 0.4$ & $\mathrm{NS}$ \\
\hline
\end{tabular}

${ }^{a}$ Number of blastomeres in the inner cell mass and trophectoderm does not match total because these cells could not be distinguished in all embryos. 
Table 3 Culture of ovine zygotes in the presence of $10 \mu \mathrm{M}$ methotrexate (MTX) alone or with $100 \mu \mathrm{M}$ hypoxanthine $(\mathrm{H})$ and $100 \mu \mathrm{M}$ thymidine (T).

\begin{tabular}{lcccc}
\hline Treatment & Control & MTX & MTX $+\mathbf{H}+\mathbf{T}$ & Significance $\boldsymbol{P}$ \\
\hline Replicate experiments & 5 & 5 & 5 & 871 \\
$\begin{array}{l}\text { Oocytes matured } \\
\text { Cleaved of inseminated, \% }\end{array}$ & 871 & 871 & $85.7 \pm 3.5$ & $\mathrm{NS}$ \\
$\begin{array}{l}\text { Blastocysts of cleaved } \\
\text { Day 7, \% }\end{array}$ & $87.8 \pm 3.3$ & $86.9 \pm 3.4$ & $48.4 \pm 3.3$ & $<0.001$ \\
$\begin{array}{l}\text { Blastocyst cell number } \\
\text { Total }\end{array}$ & $59.1 \pm 3.2$ & 0.0 & $89.8 \pm 2.9$ \\
\hline
\end{tabular}

cellular homocysteine (Pajares \& Pérez-Salab 2006). The absence of BHMT transcript expression in the bovine oocyte and pre-implantation embryo is somewhat at odds with a recent report in the human oocyte (Benkhalifa et al. 2010), mouse blastocyst (Lee et al. 2009) and our previous findings in human ES cells (Steele et al. 2005), and may reflect species-specific differences in the importance of this enzyme. It is known, for example, that the specific activity of hepatic BHMT is several fold greater in the rat than in the sheep, and this, together with the relatively low specific activity of hepatic GNMT (EC 2.1.1.20), is thought to be the principal means by which ruminants have adapted to methyl-poor diets (Snoswell \& Xue 1987). GNMT has a high $K_{\mathrm{m}}$ for SAM and so serves as a benign high-capacity methyltransferase that regulates intra-cellular transmethylation and de novo methyl group synthesis by facilitating the methylation of glycine to sarcosine (Stipanuk 2004). The absence or very low expression of transcripts for GNMT in somatic cells of the bovine follicle, but their presence in both the oocyte and blastocyst, raises intriguing questions concerning the nature and extent of SAM-mediated transmethylation reactions in these different cells, and merits further investigation.
The enzyme MAT (EC 2.5.1.6) catalyses the activation of methionine by ATP to form SAM (Fig. 1). The isoenzyme encoded by MAT1A exists as two proteins (MAT1 and MAT3) with moderate and high $K_{\mathrm{m}}$ values respectively for methionine (Stipanuk 2004). In contrast, the inter-related products of MAT2A and MAT2B have a very low $K_{\mathrm{m}}$ for methionine. In the current study, transcripts for MAT1A were absent or very poorly expressed in all the cells studied, apart from the liver, and this is in agreement with the observations of Steele et al. (2005) for human ES cells. In contrast, transcripts for MAT2A and MAT2B were expressed in all cell types, consistent with ovarian cells and embryos encountering physiological concentrations $(14-50 \mu \mathrm{M})$ of methionine in follicular and uterine fluids (Casslen 1987, Tay et al. 1997). In the current study, day 7 ovine blastocysts were capable of metabolising radio-labelled methionine to SAM and SAH (Table 4), confirming the activity of this enzyme system in ruminant embryos. However, lowlevel transcript expression of $C B S$ in cumulus and granulosa cells, relative to oocytes and thecal cells, is consistent with low intra-follicular methionine concentrations, and further indicates regional intra-follicular variation in components of the methionine cycle. Cystathionine $\beta$-synthase (CBS: EC 4.2.1.22) is the

Table 4 Culture of ovine zygotes in the presence of $10 \mu \mathrm{M}$ methotrexate (MTX) alone or with combinations of $100 \mu \mathrm{M}$ hypoxanthine (H), $100 \mu \mathrm{M}$ thymidine (T) and $25 \mu \mathrm{M}$ tetrahydrofolate (THF).

\begin{tabular}{|c|c|c|c|c|}
\hline Treatment & Control & $\mathbf{M T X}+\mathbf{H}+\mathbf{T}$ & $\mathbf{M T X}+\mathbf{H}+\mathrm{T}+\mathrm{THF}$ & Significance $P$ \\
\hline \multicolumn{5}{|l|}{ (A) Embryo development } \\
\hline Replicate experiments & 8 & 8 & 8 & \\
\hline Oocytes matured & 1239 & 1239 & 1239 & \\
\hline Cleaved of inseminated, \% & $89.3 \pm 3.8$ & $87.5 \pm 4.0$ & $88.0 \pm 4.0$ & NS \\
\hline \multicolumn{5}{|l|}{ Blastocysts of cleaved } \\
\hline Day $7, \%$ & $46.4 \pm 3.6$ & $42.2 \pm 3.6$ & $39.1 \pm 3.5$ & NS \\
\hline Replicate experiments & 4 & 4 & $\frac{1}{4}$ & \\
\hline \multicolumn{5}{|l|}{ Blastocyst cell number } \\
\hline Total & $106.4 \pm 5.1$ & $80.8 \pm 4.5$ & $91.1 \pm 4.7$ & 0.001 \\
\hline Inner cell mass & $45.9 \pm 3.4$ & $34.5 \pm 2.9$ & $37.2 \pm 3.1$ & 0.028 \\
\hline Trophectoderm & $78.4 \pm 4.4$ & $67.4 \pm 4.1$ & $72.8 \pm 4.3$ & NS \\
\hline TUNEL, \% & $5.0 \pm 1.0$ & $7.2 \pm 1.4$ & $5.9 \pm 1.2$ & NS \\
\hline \multicolumn{5}{|c|}{ (B) $\left[{ }^{35} \mathrm{~S}\right]$ methionine incorporation ${ }^{\mathrm{a}}$} \\
\hline Replicate experiments & 3 & 3 & 3 & \\
\hline SAM & $3014 \pm 235$ & $2356 \pm 234$ & $2213 \pm 234$ & 0.049 \\
\hline $\mathrm{SAH}$ & $75.92 \pm 6.5$ & $50.6 \pm 6.5$ & $50.7 \pm 6.5$ & 0.013 \\
\hline SAM:SAH & $44.1 \pm 3.6$ & $49.3 \pm 3.6$ & $49.8 \pm 3.5$ & NS \\
\hline
\end{tabular}

${ }^{\mathrm{a}}$ Incorporation of $\left[{ }^{35} \mathrm{~S}\right]$ methionine into $S$-adenosylmethionine (SAM) and $S$-adenosylhomocysteine (SAH) pools in groups of four day 7 blastocysts during a 2-h incubation. 

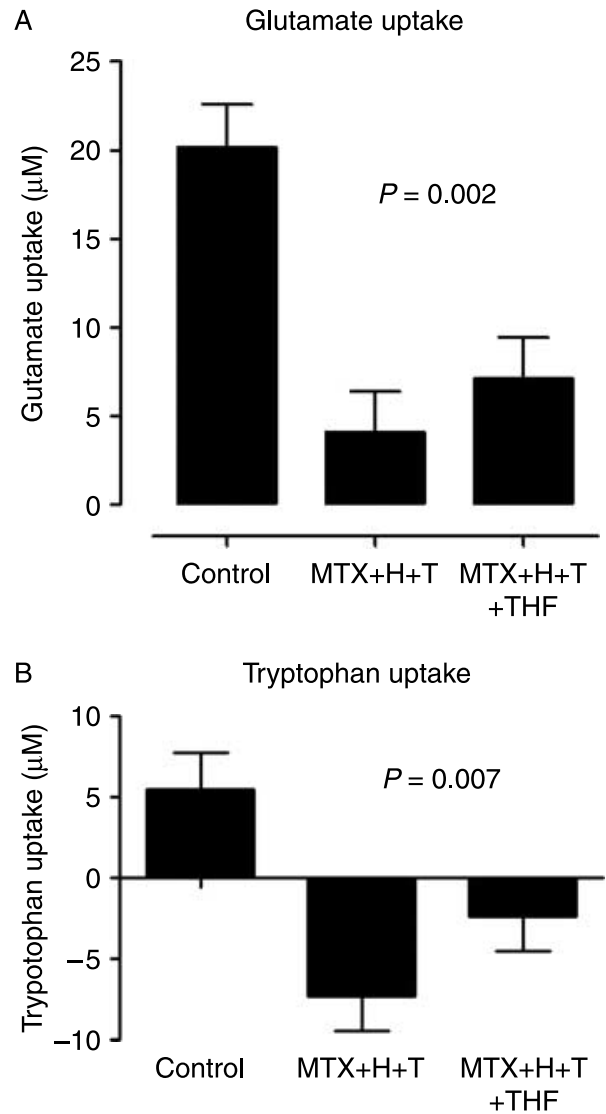

Figure 6 Net uptake of glutamate (A) and tryptophan (B) by day 6.5 ovine blastocysts following 12-h incubation. Blastocysts produced in vitro in the absence (Control) or presence of methotrexate with hypoxanthine and thymidine $(\mathrm{MTX}+\mathrm{H}+\mathrm{T})$ or methotrexate with hypoxathine, thymidine and tetrahydrafolate (MTX $+\mathrm{H}+\mathrm{T}+\mathrm{THF})$. Values $(\mu \mathrm{M})$ are adjusted to an average of 14.3 embryos by covariance analysis where number of embryos per drop formed the covariate.

rate-limiting enzyme in the trans-sulphuration pathway, and has a high $K_{\mathrm{m}}$ for homocysteine (Stipanuk 2004). Its expression was thought to be restricted to certain tissues such as the liver and kidney, but Cbs transcripts have recently been shown to be expressed in mouse cumulus cells, and functional suppression by RNA interference results in a significant increase in the number of GV-arrested oocytes (Liang et al. 2007).

\section{Folate metabolism}

The enzyme primarily responsible for the methylation of homocysteine to methionine in the ruminant liver is methionine synthase (EC 2.1.1.13), where the methyl donor is 5-methyl THF (Fig. 1). Specific activity of this enzyme in sheep hepatocytes is fourfold greater than in the rat (Snoswell \& Xue 1987). Transcripts for this vitamin $B_{12}$-dependent enzyme were expressed in all cell types studied in the current experiment, as were transcripts for all the other major folate cycle enzymes including those for dihydrofolate reductase
(DHFR; Fig. 2). DHFR (EC 1.5.1.3) catalyses THF regeneration by reduction of dihydrofolate using $\mathrm{NADPH}$ as a cofactor, and is a target for the antifolate chemotherapeutic drug MTX. MTX enters the cell via the reduced folate carrier (SLC19A1; Bosson 2003). Now, we have shown, for the first time, that SLC19A1 is expressed at all stages of mammalian embryo development up to the blastocyst stage. MTX is immediately polyglutamated by folylpolyglutamyl synthetase upon entry into the cell (Bosson 2003). Polyglutamation enhances cellular retention and increases the affinity of MTX for DHFR and three other folate-dependent enzymes involved in pyrimidine (thymidylate synthase) and purine (glycineamide ribonucleotide transformylase and aminoimidazolecarboximide ribonucleotide transformylase) synthesis (Chabner et al. 1985).

The inhibitory effects of $10 \mu \mathrm{M}$ MTX on mouse embryo development in the study of $\mathrm{O}^{\prime}$ Neill (1998) were completely reversed by the inclusion of $100 \mu \mathrm{M}$ thymidine. This is curious because mouse embryos are known to possess functional de novo purine-synthesis and purine-salvage pathways, and to be sensitive to the inclusion of purine synthesis inhibitors in culture media (Alexiou \& Lesse 1992, 1994). What is more, we found, at least in HT29 colon cancer cells, that one of the primary effects of MTX was to reduce the synthesis of purines such as adenine (Singh et al. 2006). Consequently, we elected to include the purine hypoxanthine together with the pyrimidine thymidine in our culture media. However, unlike O'Neill (1998), we were unable to completely reverse the inhibitory effects of MTX on embryo development, as evidenced by the reduced proportion of zygotes that developed to the blastocyst stage, the reduced number of blastomeres in day 8 bovine embryos and day 7 ovine embryos and the reduced uptake of glutamate and tryptophan by day 6.5 ovine embryos. Furthermore, the addition of THF to culture media was without effect. It is possible that the residual impairment in embryo development was due to the timing and level of hypoxanthine used in the current study (100 $\mu \mathrm{M}$ from the 1-cell stage), for Alexiou \& Leese (1992) reported that hypoxanthine when added at $50 \mu \mathrm{M}$ from the 1-cell stage as opposed to the 2-cell stage reduced the proportion of mouse zygotes that developed to the blastocyst stage. The mechanism underlying this effect is not known. The reduced uptake of glutamate and tryptophan (the latter amino acid donates a formate group in the synthesis of 10-formyl THF from THF) by sheep embryos, however, is indicative of depleted intracellular pools of reduced and polyglutamated folates, which cannot be corrected by exogenous THF. The kinetics of SLC19A1-mediated transport of MTX and THF into the cell cannot explain this effect (Matherly \& Goldman 2003). Instead, the effect is more likely due to the high affinity of MTX for DHFR, which is around 1000-fold that of folate (Schweitzer et al. 1990). 
Table 5 Primers used for RT-PCR analysis of transcript expression in bovine ovarian somatic cells, oocytes and embryos.

\begin{tabular}{|c|c|c|c|c|}
\hline Gene & Accession number & Primer sequence $\left(5^{\prime}-3^{\prime}\right)$ & Product length & $\begin{array}{c}\text { Annealing } \\
\text { temperature }\left({ }^{\circ} \mathrm{C}\right)\end{array}$ \\
\hline MAT1A & BC105410 & $\begin{array}{l}\text { GCC GAG CTA ACT TTC ACA GG } \\
\text { TCC CTT TGG TTC TGA CTT GG }\end{array}$ & 265 & 58 \\
\hline MAT2A & ВТ030708 & $\begin{array}{l}\text { TGG CTT GTG AAA CTG TTG CT } \\
\text { TGT GTG GAC TCT GAT GGG AA }\end{array}$ & 446 & 58 \\
\hline MAT2B & BC114151 & $\begin{array}{l}\text { ATG ATT TTC AGC CCC ATG TC } \\
\text { AAG GTG GGT TTG TTC CAT CA }\end{array}$ & 192 & 58 \\
\hline MTR & DQ084519 & $\begin{array}{l}\text { AAA CTG GGC TTC AAT CCA AA } \\
\text { CCT GAG TCT GGG CGT AGT GT }\end{array}$ & 385 & 58 \\
\hline$M T R R$ & DQ084520 & $\begin{array}{l}\text { GCA GAC ACG AGG AAG AAA GG } \\
\text { GAA GAT GTT CGA GCA GGA GG }\end{array}$ & 298 & 56 \\
\hline MTHFR & AY854631 & $\begin{array}{l}\text { GAG GCT GAT CTG AAG CAC CT } \\
\text { GGA GTG GTA GCC CTG AAT TG }\end{array}$ & 171 & 58 \\
\hline$m S H M T$ & BC103242 & $\begin{array}{l}\text { AGA ACG GGT GTT GGA ACT TG } \\
\text { TCA TCT TCA AGG AAC CCT CG }\end{array}$ & 132 & 58 \\
\hline$C B S$ & BC151539 & $\begin{array}{l}\text { TCA ACA AGA TCG GGA GGA AC } \\
\text { CGC AAG ACA TCC ACC TTC TC }\end{array}$ & 271 & 58 \\
\hline GNMT & XM_618409 & $\begin{array}{l}\text { CCT GGC TTG AGT AAG TTC CG } \\
\text { ACG TGG ATG AAA TAG CAG GG }\end{array}$ & 164 & 58 \\
\hline BHMT & AY854632 & $\begin{array}{l}\text { AAT ATC CGG GCA GAA AGT CA } \\
\text { GGT TTC CCT GAT GCT TTC AA }\end{array}$ & 261 & 58 \\
\hline$S A H H$ & ВТ030537 & $\begin{array}{l}\text { GGC CAC AGA TGT CAT GAT TG } \\
\text { GGT GAC AAA GAT GTT GCC CT }\end{array}$ & 208 & 58 \\
\hline DHFR & BC114162 & $\begin{array}{l}\text { TTC CAG AAT ATC CAG GTG TTC C } \\
\text { GGA CTC TCC CAC TTT GGG TT }\end{array}$ & 430 & 58 \\
\hline FOLR1 & XM_589186 & $\begin{array}{l}\text { GCG GCC TGC TCT TAT TGT TA } \\
\text { TTC AAA CAG TTT CCA CCA AGG }\end{array}$ & 121 & 57 \\
\hline FOLR2 & NM_001075325 & $\begin{array}{l}\text { CAC TCT GGC TCC ATG ACT GA } \\
\text { GCT GTC AGA GAA ACC CCA AG }\end{array}$ & 167 & 63.5 \\
\hline SLC19A1 & BC118431 & $\begin{array}{l}\text { GCA GCC TCT TCT TCA ACC AC } \\
\text { GGA GTT GAA GAC CCA CCA GA }\end{array}$ & 221 & 57 \\
\hline ACTB & ВТ030480 & $\begin{array}{l}\text { ACT GGG ACG ACA TGG AGA AGA T } \\
\text { TGC TCG AAG TCC AGG GCC ACG T }\end{array}$ & 442 & 57 \\
\hline
\end{tabular}

\section{Conclusions}

The current study has identified, for the first time, the presence of transcripts for most, but not for all, of the key enzymes involved in the linked methionine/folate cycles in the oocyte, ovarian follicle and pre-implantation bovine embryo. Of note was the absence of transcripts for certain enzymes involved in methionine metabolism, which may have profound implications for our understanding of how this cycle operates within the ovary and early embryo with implications for numerous intra-cellular transmethylation reactions including DNA methylation. While species-specific differences in transcript expression may account for the cellular distribution of some enzymes (e.g. BHMT), they do not appear to account for the distribution of others (e.g. MAT1A); embryonic cells in both the cow and human are devoid of transcripts for this enzyme. A comprehensive comparative analysis of transcript/protein expression for enzymes of the linked methionine/folate cycles in ovarian cells and embryos from a range of rodent and large animal species is currently underway at our laboratory and will inform on this. The bovine embryo, however, expresses transcripts for FOLR1 and SLC19A1, and SLC19A1 protein is expressed on the plasma and basal-lateral membranes throughout development up to the blastocyst stage. The mammalian pre-implantation embryo, therefore, expresses at least two important transporters to facilitate the uptake of folate. The functionality of these transporters, however, awaits further investigation. Nevertheless, the structural folate analogue and antagonist MTX is known to enter mammalian cells via SLC19A1, and here, we have demonstrated that MTX added to culture media disrupts intra-cellular folate metabolism in embryos. Indeed, the present data indicate that the pre-implantation embryo relies, to a large extent, on re-cycling endogenous pools of reduced folates, acquired during oocyte growth, primarily for the synthesis of purines and pyrimidines. These data provide an insight into the importance of maternal dietary folate status during the peri-conceptional period.

\section{Materials and Methods}

\section{Transcript analysis in bovine follicular cells and blastocysts}

Transcript expression for the enzymes described in Fig. 1 was determined by RT-PCR from RNA extracted from bovine oocytes, cumulus cells, granulosa cells, thecal cells and day 7 blastocysts. Total RNA was extracted from cumulus cells, granulosa cells and thecal cells using RNeasy Mini Kit (Qiagen Ltd). Then, $900 \mathrm{ng}$ of RNA were treated with RQ1 DNase 
(Promega) before being RT using Omniscript RT (Qiagen Ltd) in a $20-\mu \mathrm{l}$ reaction mixture. PCR was performed in a $25-\mu \mathrm{l}$ reaction mixture containing $1 \times$ ImmoMix Red (Bioline Ltd, London, UK), $20 \mathrm{pmol} / \mu \mathrm{l}$ of each primer and $0.5 \mu \mathrm{l}$ of cDNA. The PCR program consisted of a preheating step at $95{ }^{\circ} \mathrm{C}$ for $10 \mathrm{~min}$ followed by 40 cycles of $94^{\circ} \mathrm{C}$ for $15 \mathrm{~s}$, primer-specific annealing temperature (Table 5) for $15 \mathrm{~s}$ and $72{ }^{\circ} \mathrm{C}$ for $30 \mathrm{~s}$ and a final extension at $72{ }^{\circ} \mathrm{C}$ for $7 \mathrm{~min}$.

For transcript expression analysis in oocytes and embryos, poly $\mathrm{A}^{+}$RNA was extracted from pooled oocytes/embryos using Dynabeads mRNA DIRECT kit (Invitrogen Ltd). Poly A $^{+}$ RNA was RT into cDNA using QuantiTect RT kit (Qiagen Ltd) according to the manufacturer's instruction. Following DNase treatment using the kit, $1 \mu \mathrm{l}$ was removed for $-\mathrm{RT}$ reaction before RT. cDNA equivalent to two (for methyl/folate cycle enzymes) or three (for folate transporters) oocytes/embryos was used in the PCR in a total volume of $25-\mu$ reaction mix using ImmoMix Red and program as described above. PCR products $(10 \mu \mathrm{l})$ were run on agarose gels and visualised under u.v. All PCR products were sequenced to confirm primer specificity.

\section{Western blotting and immunostaining of bovine oocytes and embryos}

Goat anti-human reduced folate carrier antibody (Santa Cruz Biotechnology, Inc., Santa Cruz, CA, USA) was used at 1:400 for western blotting and at 1:100 for immunocytochemistry. Rabbit anti-human histone $\mathrm{H} 3$ antibody (Abcam, Cambridge, UK) was used at 1:20000 for western blotting.

Denuded bovine oocytes (GV stage) in PBS/PVA were mixed with sample buffer (62.5 mM Tris- $\mathrm{HCl}$, pH 6.8, 2\% SDS, 25\% glycerol, $0.01 \%$ bromophenol blue and $0.175 \mathrm{mM}$ dithiothreitol), and were boiled for $5 \mathrm{~min}$. Protein was separated on $12 \%$ SDS-PAGE, followed by transfer to PVDF membranes for $2 \mathrm{~h}$ at $80 \mathrm{~V}$ in $25 \mathrm{mM}$ Tris, $192 \mathrm{mM}$ glycine and 20\% methanol. After transfer, membranes were blocked for $1 \mathrm{~h}$ with PBS/0.1\% (v/v) Tween 20 containing 5\% milk (for reduced folate carrier antibody and histone $\mathrm{H} 3$ ) prior to incubation with the primary antibody (reduced folate carrier (RFC-1 (N-13)), Santa Cruz, Cat. no. sc-47 362) overnight at $4{ }^{\circ} \mathrm{C}$. Membranes were then washed five times in PBS/0.1\% Tween 20, followed by $1 \mathrm{~h}$ incubation with secondary antibodies (1:10 000 bovine anti-goat (Jackson ImmunoResearch Europe Ltd, Newmarket, UK), 1:20 000 goat anti-rabbit (Abcam) conjugated with HRP). Membranes were washed five times with PBS/0.1\% Tween 20 before protein bands were visualised using ECL Plus (Amersham-Pharmacia Biotech). The specificity of the reduced folate carrier antibody was confirmed by treating the antibody with tenfold excess antigenic peptide (Santa Cruz, Cat. no. sc-47362 P) prior to western blot analysis.

After removal of zona pellucida in $10 \%$ acetic acid in PBS/0.1\% (w/v) PVA, embryos were washed three times in PBS/PVA before fixing in 2.5\% paraformaldehyde (PFA) at room temperature for $10 \mathrm{~min}$. PFA-fixed embryos were permeabilised in $0.25 \%$ Triton X-100 for $15 \mathrm{~min}$ at $39{ }^{\circ} \mathrm{C}$. Fixed embryos were blocked in PBS/0.1\% PVA containing 3\% BSA and $0.1 \%$ Tween 20 for $30 \mathrm{~min}$ before incubating overnight at $4{ }^{\circ} \mathrm{C}$ with primary antibodies prepared in PBS/0.1\% PVA/0.1\% Tween 20. On the following morning, embryos were washed three times in PBS/0.1\% PVA before incubating with bovine anti-goat IgG conjugated with DyLight 549 fluorescent dye (1:400; Stratech, Suffolk, UK) for $1 \mathrm{~h}$. Embryos were washed three times in PBS/0.1\% PVA before mounting in Vectashield + DAPI (Vector Laboratories, Peterborough, UK). A negative control with the secondary antibody only was used at the same time. Samples were viewed under a Nikon confocal microscope.

\section{In vitro embryo production and assessment}

Full details of these procedures for bovine and ovine embryos were given previously (Adamiak et al. 2006, Wonnacott et al. 2010), and only a brief summary is provided here. All reagents and media used in the experiment were obtained from Sigma unless otherwise stated. Cumulus-oocyte complexes (COCs) were graded on a four-point scale by the number of compact cumulus cell layers and granulation of the oocyte cytoplasm as described previously (Wonnacott et al. 2010), and grades 1 and 2 COCs were matured in groups of up to 60 in $500 \mu \mathrm{l}$ of bicarbonated-buffered TCM199 with supplements. For fertilisation, $1 \times 10^{6}$ motile spermatozoa from a single bull or ram were added per millilitre of media containing matured oocytes (up to 60 per well), and incubated for $22 \mathrm{~h}$ at $38.8{ }^{\circ} \mathrm{C}$ in a humidified atmosphere of $5 \% \mathrm{CO}_{2}$ in air. Putative zygotes were cultured at $39{ }^{\circ} \mathrm{C}$ in a humidified atmosphere of $5 \% \mathrm{O}_{2}, 5 \% \mathrm{CO}_{2}$ and $90 \%$ $\mathrm{N}_{2}$ in groups of up to 60 in $400 \mu$ l of SOF medium with $0.3 \%$ $\mathrm{w} / \mathrm{v}$ fatty acid-free BSA, $2 \% \mathrm{v} / \mathrm{v}$ essential and $1 \% \mathrm{v} / \mathrm{v}$ non-essential amino acids (aa), and antibiotics alone (control), or with additional various combinations and levels $(0.5-10 \mu \mathrm{M})$ of MTX with or without hypoxanthine $(100 \mu \mathrm{M})$, thymidine $(100 \mu \mathrm{M})$ and THF $(25 \mu \mathrm{M})$.

Day 7 sheep and day 8 cattle blastocysts were assessed using a differential staining technique combined with TUNEL labelling, which discriminates blastomeres from the ICM from those of the TE (Fouladi-Nashta et al. 2005). Briefly, following permeabilisation, TE cells were stained with $30 \mu \mathrm{g} / \mathrm{ml}$ propidium iodide for $5 \mathrm{~min}$, and fixed in $4 \%$ PFA with $10 \mu \mathrm{g} / \mathrm{ml}$ bisbenzimide (Hoechst 33342) for 20 min prior to incubation in small droplets of In situ Cell Death Detection Kit solution (Roche) for $45 \mathrm{~min}$ at $37^{\circ} \mathrm{C}$. Following washing, embryos were mounted in small droplets of Vectashield Mounting medium (Vector Laboratories Ltd) on glass slides and examined under a Leica epiflourescent microscope (Leica, Germany).

\section{HPLC analysis of amino acids, SAM and SAH}

For amino acid analysis, day 6.5 sheep blastocyts were cultured for $12 \mathrm{~h}$ in microdrops, and following incubation, spent media were mixed with norleucine internal standard and $30 \mathrm{mg}$ of 5 -sulphosalicylic acid and were allowed to stand at $4{ }^{\circ} \mathrm{C}$ for $30 \mathrm{~min}$. After centrifugation at $16000 \mathrm{~g}$ for $10 \mathrm{~min}$ at $4{ }^{\circ} \mathrm{C}$, the supernatant was passed through a PVDF Millipore syringedriven filter unit with $0.22 \mu \mathrm{m}$ pore size, and amino acids were measured using Biochrom 20 amino acid analyser (Pharmacia LKB, Biochrom Ltd, Cambridge, UK) with ninhydrin detection (Steele et al. 2005, Singh et al. 2006). Peak integration was performed using EZChrom Elite Software (Scientific Software International Ltd, Duston, Northampton, UK). 
For analyses of SAM and SAH, groups of four day 7 sheep blastocysts were incubated for $2 \mathrm{~h}$ in SOF/PVA without essential amino acids but with $\left.{ }^{35} \mathrm{~S}\right]$ methionine $(74 \mathrm{kBq} / \mathrm{nmol}$; Amersham, AG1594), and were then extracted with $50 \mu \mathrm{l}$ of $0.4 \mathrm{M}$ perchloric acid according to the method of Sinclair et al. (2007). Briefly, following centrifugation at $10000 \mathrm{~g}$ for $15 \mathrm{~min}$ at $4{ }^{\circ} \mathrm{C}$, a $25-\mu \mathrm{l}$ aliquot of the acid extract was directly applied onto HPLC column (Zorbax, C18 column, $250 \times 4.6-\mathrm{mm}$ inner diameter, $5 \mu \mathrm{m}$ particle size). Separation was achieved using an Agilent 1100 HPLC system and u.v. detection at $254 \mathrm{~nm}$. The mobile phase consisted of two solvents: solvent $\mathrm{A}, 8 \mathrm{mM}$ octanesulphonic acid and $50 \mathrm{mM} \mathrm{NaH}{ }_{2} \mathrm{PO}_{4}, \mathrm{pH} 3.0$ and solvent B, 100\% HPLC-grade methanol. The column was equilibrated at $80 \%$ solvent $A$ and $20 \%$ solvent B before use. Following sample injection, the conditions were held at $20 \%$ solvent B for $8 \mathrm{~min}$. Then, solvent B was increased to $40 \%$ over $0.5 \mathrm{~min}$ and held there for $12.5 \mathrm{~min}$ before the initial conditions were re-established. Cold SAM and SAH standards were used to trace the radio-labelled peaks, and specific fractions were transferred to vials containing scintillation fluid and counted.

\section{Statistical analyses}

All statistical analyses were conducted using Genstat release 11.1 (Genstat 2008). The proportions of inseminated oocytes that cleaved and zygotes that developed into blastocysts were analysed by analysis of deviance using Generalised Linear Models (GLMs) assuming binomial errors and with logit link functions. Data are presented as predicted back-transformed means \pm s.E.M. Embryo cell number was analysed using a GLM assuming a Poisson error distribution and with a logit link function. Amino acid turnover during short-term embryo culture in microdrops was analysed by covariance analysis where embryo number per drop formed the covariate. Predicted means \pm S.E.M are presented.

\section{Declaration of interest}

The authors declare that there is no conflict of interest that could be perceived as prejudicing the impartiality of the research reported.

\section{Funding}

This work was supported by the University of Nottingham.

\section{Acknowledgements}

The technical assistance of Dr Dongfang Li in completing amino acid analyses is gratefully acknowledged.

\section{References}

Adamiak SJ, Powell K, Rooke JA, Webb R \& Sinclair KD 2006 Body composition, dietary carbohydrates and fatty acids determine post-fertilisation development of bovine oocytes in vitro. Reproduction 131 247-258.
Alexiou M \& Leese HJ 1992 Purine utilization, de novo synthesis and degradation in mouse preimplantation embryos. Development 114 185-192.

Alexiou M \& Leese HJ 1994 Enzymes of purine salvage and catabolism in the mouse preimplantation embryo measured by high-performance liquid-chromatography. Journal of Reproduction and Fertility 101 151-158.

Altmäe S, Stavreus-Evers A, Ruiz JR, Laanpere M, Syvänen T, Yngve A, Salumets A \& Nilsson TK 2010 Variations in folate pathway genes are associated with unexplained female infertility. Fertility and Sterility [in press]. DOI: 10.1016/j.fertnstert.2009.02.025.

Benkhalifa M, Montjean D, Cohen-Bacrie P \& Ménézo Y 2010 Imprinting: RNA expression for homocysteine recycling in the human oocyte. Fertility and Sterility [in press]. DOI: 10.1016/j.fertnstert.2009.02.081.

Bosson G 2003 Reduced folate carrier: biochemistry and molecular biology of the normal and methotrexate-resistant cell. British Journal of Biomedical Science 60 117-129.

Boxmeer JC, Steegers-Theunissen RPM, Lindemans J, Wildhagen MF, Martini E, Steegers EAP \& Macklon NS 2008 Homocysteine metabolism in the pre-ovulatory follicle during ovarian stimulation. Human Reproduction 23 2570-2576.

Casslen BG 1987 Free amino-acids in human uterine fluid - possible role of high taurine concentration. Journal of Reproductive Medicine 32 181-184.

Chabner BA, Allegra CJ, Curt GA, Clendeninn NJ, Baram J, Koizumi S, Drake JC \& Jolivet J 1985 Polyglutamation of methotrexate - is methotrexate a prodrug. Journal of Clinical Investigation 76 907-912.

Ebisch IMW, Thomas CMG, Peters WHM, Braat DDM \& SteegersTheunissen RPM 2007 The importance of folate, zinc and antioxidants in the pathogenesis and prevention of subfertility. Human Reproduction Update 13 163-174.

Forges T, Monnier-Barbarino P, Alberto JM, Gueant-Rodriguez RM, Daval JL \& Gueant JL 2007 Impact of folate and homocysteine metabolism on human reproductive health. Human Reproduction Update 13 225-238.

Fouladi-Nashta AA, Alberio R, Kafi M, Nicholas B, Campbell KHS \& Webb R 2005 Differential staining combined with TUNEL labelling to detect apoptosis in preimplantation bovine embryos. Reproductive Biomedicine Online 10 497-502.

Haggarty P, McCallum H, McBain H, Andrews K, Duthie S, McNeill G, Templeton A, Haites N, Campbell D \& Bhattachayra S 2006 Effect of B vitamins and genetics on success of in vitro fertilisation: prospective cohort study. Lancet 367 1513-1519.

Kanakkaparambil R, Singh R, Li DF, Webb R \& Sinclair KD 2009 B-vitamin and homocysteine status determines ovarian response to gonadotropin treatment in sheep. Biology of Reproduction $80743-752$.

Lee M, Slow S, Fortier A, Lever M, Garrow G, Trasler J \& Baltz JM 2009 A major source of methyl groups in blastocysts may be betaine stored by pre-implantation embryos until betaine homocysteine methyltransferase (BHMT) is transiently expressed at high levels in the inner cell mass. Biology of Reproduction 81 (Special Issue) 141.

Liang R, Yu WD, Du JB, Yang JJ, Xu J, Shang M \& Guo JZ 2007 Cystathionine $\beta$-synthase participates in murine oocyte maturation mediated by homocysteine. Reproductive Toxicology 24 89-96.

Lucock M 2000 Folic acid: nutritional biochemistry, molecular biology, and role in disease processes. Molecular Genetics and Metabolism 71 121-138.

Matherly LH \& Goldman ID 2003 Membrane transport of folates. Vitamins and Hormones 66 403-456.

Midttun O, Hustad S, Schneede J, Vollset SE \& Ueland PM 2007 Plasma vitamin B-6 forms and their relation to transsulfuration metabolites in a large, population-based study. American Journal of Clinical Nutrition 86 131-138.

O'Neill C 1998 Endogenous folic acid is essential for normal development of preimplantation embryos. Human Reproduction 13 1312-1316.

Osterhues A, Holzgreve W \& Michels KB 2009 Shall we put the world on folate? Lancet 374 959-961.

Pacchiarotti A, Mohamed MA, Micara G, Linari A, Tranquilli D, Espinola SB \& Aragona C 2007 The possible role of hyperhomocysteinemia on IVF outcome. Journal of Assisted Reproduction and Genetics 24 459-462. 
Pajares MA \& Perez-Salab D 2006 Betaine homocysteine S-methyltransferase: just a regulator of homocysteine metabolism? Cellular and Molecular Life Sciences 63 2792-2803.

Partridge RJ \& Leese HJ 1996 Consumption of amino acids by bovine preimplantation embryos. Reproduction, Fertility and Development 8 945-950.

Pront R, Margalioth EJ, Green R, Eldar-Geva T, Maimoni Z, Zimran A \& Elstein D 2009 Prevalence of low serum cobalamin in infertile couples. Andrologia 41 46-50.

Reznikoff-Etievant MF, Zittoun J, Vaylet C, Pernet P \& Milliez J 2002 Low vitamin B-12 level as a risk factor for very early recurrent abortion. European Journal of Obstetrics, Gynecology, and Reproductive Biology 104 156-159.

Ronnenberg AG, Venners SA, Xu XP, Chen CZ, Wang LH, Guang WW, Huang AQ \& Wang XB 2007 Preconception B-vitamin and homocysteine status, conception, and early pregnancy loss. American Journal of Epidemiology 166 304-312.

Schweitzer BI, Dicker AP \& Bertino JR 1990 Dihydrofolate-reductase as a therapeutic target. FASEB Journal 4 2441-2452.

Sinclair KD \& Singh R 2007 Modelling the developmental origins of health and disease in the early embryo. Theriogenology 67 43-53.

Sinclair KD, Allegrucci C, Singh R, Gardner DS, Sebastian S, Bispham J, Thurston A, Huntley JF, Rees WD, Maloney CA et al. 2007 DNA methylation, insulin resistance, and blood pressure in offspring determined by maternal periconceptional $\mathrm{B}$ vitamin and methionine status. PNAS 104 19351-19356.

Singh R, Fouladi-Nashta AA, Li D, Halliday N, Barrett DA \& Sinclair KD 2006 Methotrexate induced differentiation in colon cancer cells is primarily due to purine deprivation. Journal of Cellular Biochemistry 99 146-155.
Smith AD, Kim YI \& Refsum H 2008 Is folic acid good for everyone? American Journal of Clinical Nutrition 87 517-533.

Snoswell AM \& Xue GP 1987 Methyl-group metabolism in sheep. Comparative Biochemistry and Physiology. Part B, Biochemistry and Molecular Biology 88 383-394.

Steele W, Allegrucci C, Singh R, Lucas E, Priddle H, Denning C, Sinclair K \& Young L 2005 Human embryonic stem cell methyl cycle enzyme expression: modelling epigenetic programming in assisted reproduction? Reproductive Biomedicine Online 10 755-766.

Stipanuk MH 2004 Sulfur amino acid metabolism: pathways for production and removal of homocysteine and cysteine. Annual Review of Nutrition 24 539-577.

Tamura T \& Picciano MF 2006 Folate and human reproduction. American Journal of Clinical Nutrition 83 993-1016.

Tay JI, Rutherford AJ, Killick SR, Maguiness SD, Partridge RJ \& Leese HJ 1997 Human tubal fluid: production, nutrient composition and response to adrenergic agents. Human Reproduction 12 2451-2456.

Twigt J, Hammiche F, Sinclair KD, Beckers NG, Eijkemans RJ, Lindemans J, Laven JS \& Steegers-Theunissen RP 2009 Preconception folic acid supplementation modulates the follicular response after conventional ovarian stimulation treatment. Reproductive Sciences 16 277A-278A.

Wonnacott KW, Kwong WY, Hughes J, Salter AM, Lea RG, Garnsworthy PC \& Sinclair KD 2010 Dietary omega-3 and -6 polyunsaturated fatty acids affect the composition and development of sheep granulosa cells, oocytes and embryos. Reproduction 139 57-69.

Received 18 November 2009

First decision 8 December 2009

Accepted 18 January 2010 